\title{
HUBUNGAN ANTARA TINGGI BADAN ORANG TUA DAN PEMBERIAN ASI EKSKLUSIF TERHADAP KEJADIAN STUNTING
}

\author{
Lastri Mei Winarni ${ }^{1 *}$, Beti Prihandini², Febi Ratnasari ${ }^{3}$ \\ 1Program DIII Kebidanan STIKes Yatsi Tangerang Banten \\ 2,3Program S1 Keperawatan STIKes Yatsi Tangerang Banten \\ *Korespondensi email : lastri@stikesyatsi.ac.id
}

\section{ABSTRACT THE RELATIONSHIP BETWEEN PARENTS' HEIGHT AND EXCLUSIVE BREAST MILK ON STUNTING EVENTS}

Background : Stunting is a nutritional problem and one of them is also influenced by genetic factors (height). There was a significant increase in the incidence of stunting at the Sepatan Public Health Center where in 2018 there were 44 cases and in 2019 there were 70 cases.

Purpose : of this study was to determine the relationship between parental height and exclusive breastfeeding on the incidence of stunting in the Sepatan Public Health Center, Tangerang Regency.

Methods : used case control design. The population in this study were all children under five in the Sepatan Public Health Center, Tangerang Regency. The sample size used the Yamane formula obtained a sample of 60 respondents for each case and control with a total sample of 120 respondents. Samples were taken by purposive sampling technique. Data obtained by calling the toddler's parents or cadres and asked according to the questionnaire. Univariate and bivariate data analysis used chi square test.

Results : of the study of 120 parents in toddlers, most of them have normal father and mother height, namely 93 respondents $(77,5 \%)$ and 89 respondents $(74,2 \%)$. Most of the toddlers get exclusive breastfeeding which is 79 respondents $(65,8 \%)$. There is a relationship between maternal height and exclusive breastfeeding with the incidence of stunting with $P$ values $=0,000$ and 0,007. There is no relationship between father's height and the incidence of stunting with $P$ value $=0,190$.

Conclusion : is that there is a relationship between maternal height and exclusive breastfeeding with the incidence of stunting in the Sepatan Public Health Center, Tangerang Regency. It is recommended that regular education is needed to increase community knowledge about the growth and development of infants so that they know the factors that affect toddler growth problems, especially stunting so they are able to take action to prevent stunting.

Suggestion It is expected that health workers at the Puskesmas to provide information to the community and parents to provide exclusive breastfeeding and pay attention to good parenting, both in monitoring the nutritional state and diseases experienced by their children. Increasing the role of cadres in stunting screening for toddlers to increase the scope of stunting case finding.

Keywords: Exclusive ASI, Height, Stunting

\section{ABSTRAK}

Latar belakang : Kejadian stunting merupakan permasalah pada gizi dan salah satunya dipengaruhi juga oleh faktor genetik (tinggi badan). Terjadi peningkatan kejadian stunting yang signifikan di Puskesmas Sepatan dimana tahun 2018 sebanyak 44 kasus dan tahun 2019 sebanyak 70 kasus.

Tujuan : penelitian untuk mengetahui hubungan antara tinggi badan orang tua dan pemberian ASI eksklusif terhadap kejadian stunting di Puskesmas Sepatan Kabupaten Tangerang.

Metode : metode penelitian menggunakan case control design. Populasi dalam penelitian ini adalah seluruh balita di Puskesmas Sepatan Kabupaten Tangerang. Besaran sampel menggunakan rumus Yamane diperoleh sampel sebanyak 60 responden untuk masing-masing kasus dan kontrol dengan total sampel 120 responden. Sampel diambil dengan teknik purposive sampling. Data diperoleh dengan cara menelpon orang tua balita atau kader dan menanyakan sesuai dengan kuesioner. Analisa data secara univariat dan bivariat dengan menggunakan uji chi square.

Hasil : hasil penelitian dari 120 orang tua pada balita, sebagian besar memiliki tinggi badan ayah dan ibu yang normal yaitu 93 responden $(77,5 \%)$ dan 89 responden $(74,2 \%)$. Balita sebagian besar mendapatkan ASI 


\section{JKM (Jurnal Kebidanan Malahayati),Vol 7,No.4.Oktober 2021, ISSN (Print) 2476-8944 ISSN (Online) 2579-762X, Hal 688-696}

eksklusif yaitu sebanyak 79 responden $(65,8 \%)$. Terdapat hubungan antara tinggi badan ibu dan pemberian ASI eksklusif dengan kejadian stunting dengan $P$ value $=0,000$ dan 0,007 . Tidak terdapat hubungan tinggi badan ayah dengan kejadian stunting dengan $P$ value $=0,190$.

Kesimpulan : ada hubungan antara tinggi badan ibu dan pemberian ASI eksklusif dengan kejadian stunting di Puskesmas Sepatan Kabupaten Tangerang. Disarankan perlunya edukasi secara rutin untuk meningkatkan pengetahuan masyarakat tentang pertumbuhan dan perkembangan balita sehingga mengetahui faktor yang mempengaruhi permasalahan pertumbuhan balita khususnya stunting sehingga mampu melakukan tindakan pencegahan kejadian stunting.

Saran Diharapkan petugas kesehatan di Puskesmas agar memberikan informasi kepada masyarakat dan orang tua agar memberikan ASI Eksklusif dan memperhatikan pola asuh yang baik, baik dalam pemantauan keadaan gizi dan penyakit yang dialami oleh anaknya. Meningkatkan peran kader dalam scrining stunting pada balita untuk meningkatkan cakupan penemuan kasus stunting.

Kata Kunci: ASI Eksklusif, Stunting, Tinggi Badan

\section{PENDAHULUAN}

Stunting merupakan permasalahan yang terjadi pada tumbuh dan kembang anak dikarenakan mengalami gizi buruk, adanya infeksi yang berulang dan dorongan psikososial yang kurang memadai. Kata stunted diberikan pada anak yang tinggi badan anak sesuai usia berada dibawah nilai dua standar deviasi Median Pertumbuhan Anak (Ohyver et al., 2017). Proses stunting dapat dimulai saat janin dalam kadungan yang akan terlihat saat ketika anak memasuki usia ditahun kedua. Di Indonesia masalah stunting merupakan adanya masalah dalam gizi nasional karena hal ini dapat berakibat pada fisik dan fungsional tubuh anak serta angka kesakitan yang meningkat pada anak (Kemenkes, 2018).

Menurut WHO tahun 2016, prevalensi balita stunting di dunia sebesar $22,9 \%$ dan keadaan gizi balita pendek menjadi penyebab 2,2 juta dari seluruh penyebab kematian balita di seluruh dunia. Hampir setengah tingkat kematian pada anak-anak di bawah lima tahun di Asia dan Afrika disebabkan oleh kekurangan gizi. Ini menyebabkan kematian tiga juta anak per tahun (Ohyver et al., 2017).

Berdasarkan data WHO tahun 2016 di wilayah Asia Tenggara prevalensi balita stunting mencapai 33,8\% (Ohyver et al., 2017). Jika prevalensi balita stunting di Indonesia dibandingkan dengan Vietnam sebanyak $23 \%$, Malaysia $17 \%$, Thailand $16 \%$ dan Singapura 4\%. Jika merujuk data dari Global Nutrition Report (2014) Indonesia berada dalam posisi 17 negara dari 117 negara yang memiliki permasalahan gizi pada balita yaitu stunting, wasting dan kelebihan berat badan. Berdasarkan hasil Riskesdas (2018) untuk prevalensi stunting pada balita sebesar 30,8\% dengan kategori sangat pendek $11,5 \%$ dan kategori pendek 19,3\%. Data stunting tahun 2018 tersebut sudah terjadi penurunan dibandingkan data stunting tahun 2013 sebesar 37,2\% (Kementrian Kesehatan $\mathrm{RI}, 2018$ ).

Berdasarkan Riskesdas Tahun 2018, proporsi status gizi sangat pendek dan pendek menurut provinsi paling tinggi yaitu di Nusa Tenggara Timur yang mencapai $42,6 \%$ dan terendah di DKI Jakarta sebesar 17,7\%. Banten merupakan salah satu provinsi dengan prevalensi yang cukup tinggi walaupun masih dibawah ratarata Nasional yaitu $25,7 \%$. Secara keseluruhan, pada awal 2019, di Banten ada sebanyak 2.934 anak menderita stunting (Kementrian Kesehatan RI, 2018).

Kabupaten Tangerang terdiri dari 44 Puskesmas, Puskesmas Sepatan merupakan salah satu Puskesmas dengan kasus stunting di Kabupaten Tangerang. Berdasarkan laporan tahunan diketahui bahwa terdapat peningkatan kasus stunting di Puskesmas Sepatan tahun 2018 sebanyak 44 kasus dan tahun 2019 sebanyak 70 kasus. Kondisi tersebut menunjukkan bahwa stunting mengalami peningkatan secara signifikan.

Kejadian stunting merupakan permasalah pada gizi yang dipengaruhi oleh tatanan ekonomi maupun sosial masyarakat. Dalam proses selanjutnya hal ini akan berdampak pada kesehatan, permasalahan dalam pendidikan dan produktifitas di masa depan. Faktor penyebab stunting terdiri dari faktor basic seperti faktor ekonomi dan pendidikan ibu, kemudian faktor intermedien seperti jumlah anggota keluarga, tinggi badan orang tua, dan jumlah anak ibu. Selanjutnya adalah faktor proximal seperti pemberian ASI eksklusif, usia anak dan BBLR (Sastria, 2019).

Penelitian terkait pemberian ASI eksklusif sudah dilakukan oleh Satria dkk (2019) dimana didapatkan hubungan antara faktor pemberian ASI dengan kejadian stunting $(p$ value $=0,001)$. Penelitian Sulistianingsih dan Sari (2018) 
membuktikan bahwa ASI eksklusif berpengaruh terhadap stunting dimana balita yang memperoleh ASI eksklusif berisiko 9,3 kali lebih kecil untuk terjadi stunting dibandingkan balita yang tidak memperoleh ASI eksklusif. Penelitian Christin, Agung dan Humairoh (2018) didapatkan bahwa ada hubungan antara pemberian ASI eksklusif dengan kejadian stunting balita usia 6-23 bulan ( $p$ value $=$ 0,028) (Sastria, 2019; Sulistianingsih \& Sari, 2018).

Penyebab stunting selain faktor langsung, ada faktor tidak langsung salah satunya adalah genetik. Genetik yang diturunkan dapat berupa tinggi badan kedua orang tua. Pengukuran tinggi badan dapat dilakukan dengan microtoise dalam ketelitian $0,1 \mathrm{~cm}$ dari ujung kaki sampai kepala. Tinggi badan seorang ibu dikatakan kategori pendek bila $<150 \mathrm{~cm}$ dan normal $\geq 150 \mathrm{~cm}$. Untuk tinggi badan ayah kategori pendek bila $<155 \mathrm{~cm}$ dan normal bila $\geq 155 \mathrm{~cm}$ (Ratu dkk, 2018). Orang tua yang memiliki genetik pendek dapat mewariskan kepada anaknya sehingga anak akan berpeluang untuk tumbuh pendek atau stunting (Nasikhah \& Margawati, 2012).

Penelitian Ratu dkk. (2018) menyatakan adanya hubungan tinggi badan ibu dengan kejadian stunting dan tidak ada hubungan tinggi badan ayah dengan kejadian stunting pada anak usia 24-59 bulan di Kecamatan Ratahan Kabupaten Minahasa Tenggara. Penelitian Fotrihadi (2018) membuktikan bahwa ada hubungan antara tinggi badan ibu dengan stunting pada balita usia 24-59 bulan di wilayah kerja Puskesmas Wonosari I. Barir dkk. (2019) menyatakan stunting secara langsung dan negatif dipengaruhi oleh panjang lahir $\geq 48 \mathrm{~cm}$, berat lahir $\geq 2500 \mathrm{gr}$, pemberian ASI eksklusif, pemberian makanan pendamping ASI secara tepat waktu. Secara tidak langsung dipengaruhi oleh pendapatan keluarga, usia ibu, sikap, tinggi ibu > $150 \mathrm{~cm}$, pekerjaan, pendidikan dan pengetahuan (Ratu et al., 2010).

Stunting dapat dicegah dengan beberapa hal seperti memberikan ASI Esklusif, memberikan makanan yang bergizi sesuai kebutuhan tubuh, membiasakan perilaku hidup bersih, melakukan aktivitas fisik, untuk menyeimbangkan antara pengeluaran energi dan pemasukan zat gizi kedalam tubuh, dan memantau tumbuh kembang anak secara teratur (Amin \& Julia, 2016).

Belum ada penelitian di Banten khususnya di wilayah Puskesmas Sepatan terkait dengan hubungan pemberian ASI eksklusif dan tinggi badan orang tua dengan stunting, oleh karena itu peneliti tertarik untuk mengadakan penelitian tentang "Hubungan antara tinggi badan orang tua dan pemberian ASI eksklusif dengan kejadian stunting di Puskesmas Sepatan Kabupaten Tangerang".

\section{METODE PENELITIAN}

Jenis penelitian yang digunakan adalah jenis penelitian kuantitatif dengan rancangan penelitian case control atau retrospective study. Penelitian dilakukan di Puskesmas Sepatan Kabupaten Tangerang. Puskesmas Sepatan merupakan salah satu Puskesmas dengan kasus stunting di Kabupaten Tangerang. Berdasarkan laporan tahunan diketahui bahwa terdapat peningkatan kasus stunting di Puskesmas Sepatan tahun 2018 sebanyak 44 kasus dan tahun 2019 sebanyak 70 kasus. Kondisi tersebut menunjukkan bahwa stunting mengalami peningkatan secara signifikan. Waktu penelitian dilaksanakan pada bulan Mei 2019.

Setelah dilakukan pendataan dan informed consent dari 70 anak stunting yang teridentifikasi, hanya 60 orang tua yang setuju menandatangi infomed consent. Oleh karena itu sampel penelitian ini adalah 60 kelompok kasus (balita stunting) dan 60 kelompok kontrol (balita normal), sehingga total sampelnya sebanyak 120 balita. Teknik sampling dalam penelitian menggunakan purposive sampling. Kriteria inklusi untuk kelompok kasus yaitu balita usia 1-5 tahun tercatat sebagai balita stunting di Puskemas Sepatan; orang tua bersedia menjadi responden; orang tua dapat berkomunikasi dengan baik (menggunakan bahasa Indonesia); orang tua memiliki handphone. Kriteria inklusi untuk kelompok kontrol yaitu balita usia 1-5 tahun tercatat sebagai balita normal di Puskesmas Sepatan; orang tua bersedia menjadi responden; orang tua dapat berkomunikasi dengan baik (menggunakan bahasa Indonesia); orang tua memiliki handphone. Sedangkan kriteria eksklusi untuk kasus dan kontrol adalah balita yang lahir dengan BBLR; balita dengan penyakit kronis; balita dengan cacat bawaan.

Pengumpulan data dilakukan dengan menggunakan kuesioner dan lembar pengukuran tinggi badan. Untuk kuesioner terdiri dari karakteristik responden (umur, jenis kelamin) dan pemberian ASI eksklusif. Analisa data dilakukan secara univariat dan untuk analisa bivariat menggunakan uji Chi square $\left(x^{2}\right)$.

\section{HASIL DAN PEMBAHASAN \\ Karakteristik Responden}

Berdasarkan tabel dibawah diketahui bahwa dari 120 balita sebagian berumur 3-5 Tahun yaitu sebanyak 90 responden $(75,0 \%)$, sebagian besar 
JKM (Jurnal Kebidanan Malahayati),Vol 7,No.4.Oktober 2021,

ISSN (Print) 2476-8944 ISSN (Online) 2579-762X, Hal 688-696

berjenis kelamin laki-laki yaitu 66 responden $(55,0 \%)$.

Tabel 1.

Gambaran Karakteristik Responden

\begin{tabular}{lcc}
\hline \multicolumn{1}{l}{ Karakteristik Responden } & f & $\%$ \\
\hline Umur & & \\
$1-<3$ Tahun & 30 & 25,0 \\
$3-5$ Tahun & 90 & 75,0 \\
Jenis Kelamin & & \\
Laki-laki & 66 & 55,0 \\
Perempuan & 54 & 45,0 \\
\hline$\quad$ Total & 120 & 100,0 \\
\hline
\end{tabular}

Sumber : Data Primer 2020

\section{Analisa Univariat}

Berdasarkan tabel 2 diketahui bahwa dari 120 responden ayah pada balita, sebagian besar memiliki tinggi badan normal yaitu 93responden $(77,5 \%)$, sebagian besar tinggi badan ibu dalam kategori normal yaitu 89 responden $(74,2 \%)$ dan sebagian besar balita mendapatkan ASI eksklusif yaitu sebanyak 79 responden $(65,8 \%)$.

Tabel 2.

Distribusi Frekuensi Tinggi Badan Ayah, Tinggi Badan Ibu dan Pemberian ASI

\begin{tabular}{lcc}
\hline \multicolumn{1}{c}{ Variabel } & f & \% \\
\hline Tinggi Badan Ayah & & \\
Pendek & 27 & 22,5 \\
Normal & 93 & 77,5 \\
Tinggi Badan Ibu & & \\
Pendek & 31 & 25,8 \\
Normal & 89 & 74,2 \\
Pemberian ASI & & \\
Tidak Eksklusif & 41 & 34,2 \\
Eksklulsif & 79 & 65,8 \\
\hline Total & 120 & 100,0 \\
\hline Sumber : Data Primer 2020 & &
\end{tabular}

Analisis Bivariat

Tabel 3.

Hubungan Tinggi Badan Ayah dengan Kejadian Stunting

\begin{tabular}{|c|c|c|c|c|c|c|c|c|}
\hline \multirow{3}{*}{$\begin{array}{c}\text { Tinggi Badan } \\
\text { Ayah }\end{array}$} & \multicolumn{4}{|c|}{ Kejadian Stunting } & \multirow{2}{*}{\multicolumn{2}{|c|}{ Total }} & \multirow{3}{*}{$\begin{array}{c}\text { OR } \\
(95 \% \mathrm{Cl})\end{array}$} & \multirow{3}{*}{$P$ Value } \\
\hline & \multicolumn{2}{|c|}{$Y a$} & \multicolumn{2}{|c|}{ Tidak/ Normal } & & & & \\
\hline & $\mathrm{n}$ & $\%$ & $\mathrm{n}$ & $\%$ & $\mathbf{n}$ & $\%$ & & \\
\hline Pendek & 17 & 14,17 & 10 & 8,33 & 27 & 22,50 & 1,977 & \\
\hline Normal & 43 & 35,83 & 50 & 41,67 & 93 & 77,50 & $(0,819-4,771)$ & 0,190 \\
\hline Jumlah & 60 & 50,00 & 60 & 50,00 & 120 & 100,0 & & \\
\hline
\end{tabular}

Sumber : Data Primer 2020

Berdasarkan tabel 3 didapatkan hasil dari 60 balita yang mengalami kejadian stunting sebagian besar yaitu $43(35,83 \%)$ dengan ayah yang memiliki tinggi badan normal, sedangkan dari 60 balita yang tidak mengalami kejadian stunting (normal) sebagian besar yaitu $50(41,67 \%)$ dengan ayah yang memiliki tinggi badan normal.

Hasil uji chi square $\left(x^{2}\right)$ diperoleh nilai $p$ value $0,190(>0,05)$ dapat disimpulkan bahwa tidak terdapat hubungan tinggi badan ayah dengan kejadian stunting di Puskesmas Sepatan Kabupaten Tangerang.

Tabel 4.

Hubungan Tinggi Badan Ibu dengan Kejadian Stunting

\begin{tabular}{|c|c|c|c|c|c|c|c|c|}
\hline \multirow{3}{*}{$\begin{array}{c}\text { Tinggi Badan } \\
\text { lbu }\end{array}$} & \multicolumn{4}{|c|}{ Kejadian Stunting } & \multirow{2}{*}{\multicolumn{2}{|c|}{ Total }} & \multirow{3}{*}{$\begin{array}{c}\text { OR } \\
(95 \% \mathrm{Cl})\end{array}$} & \multirow{3}{*}{$\begin{array}{c}P \\
\text { Value }\end{array}$} \\
\hline & \multicolumn{2}{|c|}{$\mathrm{Ya}$} & \multicolumn{2}{|c|}{ Tidak/ Normal } & & & & \\
\hline & $\mathrm{n}$ & $\%$ & $\mathrm{n}$ & $\%$ & $\mathrm{n}$ & $\%$ & & \\
\hline Pendek & 25 & 20,83 & 6 & 5,00 & 31 & 25,83 & 6,429 & \\
\hline Normal & 35 & 29,17 & 54 & 45,00 & 89 & 74,17 & $(2,395-17,254)$ & 0,000 \\
\hline Jumlah & 60 & 50,00 & 60 & 50,00 & 120 & 100,0 & & \\
\hline
\end{tabular}

Sumber : Data Primer 2020

Berdasarkan tabel 4 didapatkan hasil dari 60 balita yang mengalami kejadian stunting sebagian besar yaitu $35(29,17 \%)$ dengan ibu yang memiliki tinggi badan normal, sedangkan dari 60 balita yang 
tidak mengalami kejadian stunting (normal) sebagian besar ada $54(45 \%)$ dengan ibu yang memiliki tinggi badan normal.

Hasil analisa diperoleh nilai $p$ value $0,000(<$ $0,05)$ yang artinya terdapat hubungan tinggi badan ibu dengan kejadian stunting dengan $\mathrm{OR}=6,429$ yang berarti balita dengan ibu tinggi badan pendek berpeluang 6 kali lebih besar mengalami stunting dibandingkan dengan balita dengan ibu tinggi normal.

Tabel 5.

Hubungan Pemberian ASI Eksklusif dengan Kejadian Stunting

\begin{tabular}{|c|c|c|c|c|c|c|c|c|}
\hline \multirow{3}{*}{$\begin{array}{c}\text { Pemberian } \\
\text { ASI }\end{array}$} & \multicolumn{4}{|c|}{ Kejadian Stunting } & \multirow{2}{*}{\multicolumn{2}{|c|}{ Total }} & \multirow{3}{*}{$\begin{array}{c}\text { OR } \\
(95 \% \mathrm{Cl})\end{array}$} & \multirow{3}{*}{$\begin{array}{c}P \\
\text { Value }\end{array}$} \\
\hline & \multicolumn{2}{|c|}{$\mathrm{Ya}$} & \multicolumn{2}{|c|}{ Tidak/ Normal } & & & & \\
\hline & $\mathbf{n}$ & $\%$ & $\mathrm{n}$ & $\%$ & $\mathrm{n}$ & $\%$ & & \\
\hline Tidak Eksklusif & 28 & 23,33 & 13 & 10,83 & 41 & 34,16 & 3,163 & \\
\hline Eksklusif & 32 & 26,67 & 47 & 39,17 & 79 & 65,84 & $(1,426-7,016)$ & $0,00 /$ \\
\hline Jumlah & 60 & 50 & 60 & 50 & 120 & 100 & & \\
\hline
\end{tabular}

Sumber : Data Primer 2020

Berdasarkan tabel 5 dari 60 balita yang mengalami kejadian stunting sebagian besar yaitu 32 responden $(26,67 \%)$ yang mendapatkan ASI eksklusif, sedangkan dari 60 balita yang tidak mengalami kejadian stunting (normal) sebagian besar yaitu 47 responden $(39,17 \%)$ yang mendapatkan ASI eksklusif.

Hasil analisa diperoleh nilai $p$ value $0,007<$ $0,05)$ dapat disimpulkan bahwa Ho ditolak yang artinya terdapat hubungan antara pemberian ASI eksklusif dengan kejadian stunting di Puskesmas Sepatan Kabupaten Tangerang dengan OR $=3,163$ (95\% Cl: 1,426-7,016) yang berarti balita yang tidak mendapatkan ASI eksklusif berpeluang 3 kali lebih besar mengalami stunting dibandingkan dengan balita yang mendapatkan ASI eksklusif.

\section{PEMBAHASAN}

\section{Umur}

Hasil penelitian didapatkan bahwa dari 120 balita sebagian berumur 3-5 tahun yaitu sebanyak 90 responden $(75,0 \%)$. Hasil ini sejalan dengan hasil penelitian Sumirta dkk. (2019) di Panyileukan Bandung yang berjudul hubungan tinggi badan orang tua dengan kejadian stunting pada balita, menyebutkan sebagian besar balita berusia 37-56 bulan sebanyak 56 (51,4\%). Penelitian Mikawati, Lusiana dan Hasriany (2019) yang menyatakan bahwa dari 49 balita sebagian besar berusia $>3$ tahun yaitu sebanyak 25 (51\%) (Surmita et al., 2019). Masa balita merupakan usia paling rawan karena pada masa ini balita sering terkena penyakit infeksi sehingga menjadikan anak berisiko tinggi menjadi kurang gizi. Pada usia prasekolah yaitu usia 2 - 6 tahun, anak mengalami pertumbuhan yang stabil, terjadi perkembangan dengan aktifitas jasmani yang bertambah dan meningkatnya keterampilan dan proses berpikir.
Prevalensi stunting lebih banyak pada anak usia 24 - 59 bulan, hal ini menunjukkan bahwa stunting tidak mungkin reversible. Selain itu, pada usia 3 - 5 tahun atau yang bisa juga disebut usia prasekolah kecepatan pertumbuhannya (growth velocity) sudah melambat. Gangguan pertumbuhan linier terjadi terutama dalam 2 sampai 3 tahun pertama kehidupan anak yang merupakan cerminan dari efek interaksi antara kurangnya asupan energi dan zat gizi serta infeksi (Cleaton-Jones et al., 2000).

Peneliti berpendapat bahwa pertumbuhan pada usia balita dan prasekolah lebih lambat dibandingkan pada masa bayi namun pertumbuhannya stabil. Memperlambatnya kecepatan pertumbuhan ini tercermin dalam penurunan nafsu makan, padahal dalam masa ini anak-anak membutuhkan kalori dan zat gizi yang adekuat untuk memenuhi kebutuhan akan zat gizi mereka.

\section{Jenis Kelamin}

Berdasarkan hasil penelitian bahwa dari 120 balita sebagian besar berjenis kelamin laki-laki yaitu 66 responden $(55,0 \%)$. Dari 60 balita stunting sebagian besar berjenis kelamin laki-laki yaitu 33 $(65 \%)$. Hasil ini sejalan dengan Mugianti dkk. (2018) menunjukkan bahwa dari 31 anak dengan stunting di Kecamatan Sukorejo berjenis kelamin laki-laki sebanyak 20 anak (64,5\%). Penelitian Amin dan Julia (2014) menunjukkan bahwa dari 126 balita stunting sebagian besar yaitu $66(52,8 \%)$ berjenis kelamin laki-laki (Mugianti et al., 2018). Proporsi balita laki-laki berstatus gizi stunting lebih banyak dibanding bayi perempuan. Laki-laki 1,77 kali lebih berisiko menjadi stunting. Kebiasaan di masyarakat yang cenderung lebih memerhatikan makanan anak perempuan dibanding laki-laki, 


\section{JKM (Jurnal Kebidanan Malahayati),Vol 7,No.4.Oktober 2021, \\ ISSN (Print) 2476-8944 ISSN (Online) 2579-762X, Hal 688-696}

pemberian makanan tambahan lebih dini, dan kejadian diare yang lebih banyak pada bayi laki-laki turut berpengaruh (Torlesse et al., 2016).

Peneliti berasumsi bahwa jenis kelamin baik anak perempuan dan laki-laki berisiko untuk menjadi stunting. Jenis kelamin juga tidak dibedakan dalam menentukan kebutuhan energi dan zat gizi anak balita. Jenis kelamin hanya dibedakan untuk menentukan status gizi anak usia balita.

\section{Tinggi Orang Tua}

Hasil analisis didapatkan bahwa dari 120 responden, sebagian besar memiliki ayah dengan tinggi badan normal yaitu 93 responden $(77,5 \%)$ dan ibu dengan tinggi badan normal yaitu 89 responden $(74,2 \%)$. Hasil ini sejalan dengan penelitian Surmita dkk. (2019) yang menyatakan bahwa besar balita yang mengikuti penelitian ini mempunyai tinggi badan normal $(80,7 \%)$. Tinggi badan ibu sebagian besar adalah normal $(76,1 \%)$. Penelitian Ratu dkk. (2018), berdasarkan hasil uji tinggi badan ayah pendek sebanyak $34,1 \%$ dan untuk tinggi badan ayah normal sebanyak $65,9 \%$. Sedangkan untuk tinggi badan ibu normal sebanyak 49 orang $(55,7 \%)$ dan yang pendek sebanyak 39 orang (44,3\%) (Surmita et al., 2019).

Orang tua yang memiliki tubuh pendek karena kekurangan hormon pertumbuhan akan memiliki gen kromosom dengan sifat pendek yang akan diwariskan sehingga anak berisiko untuk tumbuh pendek/stunting. Namun jika orang tua bertubuh pendek dikarenakan asupan gizi yang kurang atau suatu penyakit, kemungkinan anak akan tumbuh dengan tinggi badan yang normal selama anak mendapatkan asupan gizi yang baik dan tersebut tidak ada faktor risiko lain (Nasikhah \& Margawati, 2012).

Tinggi badan merupakan salah satu bentuk dari ekspresi genetik, dan merupakan faktor yang diturunkan kepada anak serta berkaitan dengan kejadian stunting. Anak dengan orang tua yang pendek, baik salah satu maupun keduanya, lebih berisiko untuk tumbuh pendek dibanding anak dengan orang tua yang tinggi badannya normal. Orang tua yang pendek karena gen dalam kromosom yang membawa sifat pendek kemungkinan besar akan menurunkan sifat pendek tersebut kepada anaknya. Tetapi bila sifat pendek orang tua disebabkan karena masalah nutrisi maupun patologis, maka sifat pendek tersebut tidak akan diturunkan kepada anaknya (Kemenkes, 2018).

Peneliti berasumsi bahwa orang tua dengan tinggi normal namun memiliki anak stunting bisa saja terjadi karena tinggi badan anak dipengaruhi oleh berbagai macam faktor. Tinggi badan merupakan status gizi yang diperoleh dalam jangka waktu panjang yang merupakan hasil interaksi antara faktor genetik, asupan zat gizi makro dan mikro.

\section{ASI Eksklusif}

Hasil analisis menunjukkan bahwa dari 120 responden balita sebagian besar mendapatkan ASI eksklusif yaitu sebanyak 79 responden $(65,8 \%)$. Hasil ini sejalan dengan penelitian Satria dkk. (2019) yang menyebutkan bahwa sebagian besar balita di Kecamatan Sukorejo Kota Blitarmendapatkan ASI eksklusif 31 (59.6\%). Penelitian Mugianti dkk (2018) menunjukkan bahwa 67,7\% (21 anak) mendapatkan ASI Eksklusif dan 32,3\% (10 anak) tidak mendapatkan ASI Eksklusif (Sastria, 2019).

Air Susu Ibu/ASI sangat penting dalam memenuhi nutrisi maupun gizi bayi dalam awal kehidupan sampai usia 6 bulan dan setelahnya bayi dapat mulai dikenalkan makanan tambahan. Selain itu ASI mengandung tiga perempat sumber protein dan asam amino penting yang dibutuhkan bayi sehingga ASI menjadi sumber utama makanan bayi yang mudah didapat. Pada dasarnya ASI memiliki manfaat sebagai sumber protein berkualitas baik dan mudah didapat, meningkatkan imunitas anak dan dapat memberikan efek terhadap status gizi anak dan mempercepat pemulihan bila sakit serta membantu menjalankan kelahiran. Peneliti berasumsi bahwa ASI Eksklusif penting dalam pertumbuhan anak untuk mengurangi dan mencegah terjadinya penyakit infeksi pada anak. Masih adanya perilaku ibu yang tidak memberikan ASI eksklusif karena ketidaktahuan tentang pentingnya ASI Eksklusif.

\section{Hubungan Tinggi Badan Ayah dengan Kejadian Stunting}

Hasil analisis antara tinggi badan ayah dengan kejadian stunting diketahui bahwa dari 60 balita yang mengalami kejadian stunting sebagian besar yaitu $43(35,83 \%)$ dengan ayah yang memiliki tinggi badan normal, sedangkan dari 60 balita yang tidak mengalami kejadian stunting (normal) sebagian besar yaitu $50(41,67 \%)$ dengan ayah yang memiliki tinggi badan normal. Analisis lanjut dengan uji chi square $\left(x^{2}\right)$ diperoleh nilai $p$ value $0,190(>0,05)$ dengan menggunakan alpha $5 \%$ $(0,05)$ dapat disimpulkan bahwa Ho diterima yang artinya tidak terdapat hubungan tinggi badan ayah dengan kejadian stunting di Puskesmas Sepatan Kabupaten Tangerang. 
Hasil ini sejalan dengan penelitian Ratu dkk. (2018) menyatakan tidak ada hubungan tinggi badan ayah dengan kejadian stunting pada anak usia 24-59 bulan di Kecamatan Ratahan Kabupaten Minahasa Tenggara. Penelitian Amin dan Julia (2014) membuktikan bahwa tidak terdapat hubungan tinggi badan ayah dengan kejadian stunting pada pada balita usia 6-23 bulan di Kecamatan Sedayu, Bantul, Yogyakarta (Ratu et al., 2010).

Ada beberapa faktor yang dapat mempengaruhi terhadap tinggi badan orang tua yaitu faktor genetic atau faktor nutrisi maupun patologis. Tinggi badan ibu merupakan salah satu faktor yang dapat berpengaruh terhadap stunting karena keluarga termasuk dalam faktor internal yang mempengaruhi pertumbuhan dan perkembangan karena kecenderungan keluarga dalam memiliki tubuh yang tinggi maupun pendek serta faktor genetik menjadi salah satu faktor yang dapat berpengaruh dimana ada beberapa kelainan genetik yang berpengaruh terhadap tubuh kembang seperti halnya kerdil (Ratu et al., 2010).

Tinggi badan orang tua berpengaruh terhadap tinggi badan anak. Faktor genetik dapat memengaruhi tinggi badan sampai dengan $15 \%$. Artinya apabila orang tua pendek, anaknya mempunyai kemungkinan untuk pendek atau stunting. Menurut Amin (2016) stunting dipengaruhi oleh genetik, tinggi badan orang tua yang pendek ada kemungkinan akan diturunkan kepada anaknya (Amin \& Julia, 2016). Peneliti berasumsi bahwa tidak adanya hubungan tinggi badan ayah dengan stunting bisa saja terjadi karena faktor genetik bukan satu-satunya yang menentukan tinggi badan seorang anak, ada faktor yang berperan. Selain itu bisa saja tinggi badan ayah yang tidak normal bukan dari kelainan kromosom melainkan karena faktor asupan gizi yang kurang baik dan faktor risiko lain dimasa lalu. Dalam penelitian ini tidak diteliti faktor-faktor yang mempengaruhi tinggi badan orang tua, sehingga tidak bisa dibedakan apakah tinggi badan orang tua saat ini merupakan pengaruh genetik atau karena pengaruh patologis maupun malnutrisi.

\section{Hubungan Tinggi Badan lbu dengan Kejadian Stunting}

Hasil analisis antara tinggi badan ibu dengan kejadian stunting diketahui bahwa dari 60 balita yang mengalami kejadian stunting sebagian besar yaitu $35(29,17 \%)$ dengan ibu yang memiliki tinggi badan normal, sedangkan dari 60 balita yang tidak mengalami kejadian stunting (normal) sebagian besar ada 54 (45\%) dengan ibu yang memiliki tinggi badan normal. Hasil analisis lanjut dengan chi square $\left(x^{2}\right)$ diperoleh nilai $p$ value 0,000 $(<0,05)$ dengan menggunakan alpha $5 \%(0,05)$ dapat disimpulkan bahwa Ho ditolak yang artinya terdapat hubungan tinggi badan ibu dengan kejadian stunting di Puskesmas Sepatan Kabupaten Tangerang dengan OR $=6,429(95 \% \mathrm{Cl}$ : 2,395$17,254)$ yang berarti balita dengan ibu tinggi badan pendek berpeluang 6 kali lebih besar mengalami stunting dibandingkan dengan balita dengan ibu tinggi normal.

Hasil ini sejalan dengan penelitian Ratu dkk. (2018) menyatakan adanya hubungan tinggi badan ibu dengan kejadian stunting pada anak usia 24-59 bulan di Kecamatan Ratahan Kabupaten Minahasa Tenggara (Ratu et al., 2010). Penelitian Fotrihadi (2018) membuktikan bahwa ada hubungan antara tinggi badan ibu dengan stunting pada balita usia 24-59 bulan di wilayah kerja Puskesmas Wonosari I. Penelitian Barir dkk. (2019) menyatakan stunting secara tidak langsung dipengaruhi oleh, tinggi ibu > $150 \mathrm{~cm}$ pada balita di Jombang Jawa Timur ( Barir et al., 2019).

Tinggi badan pada orang tua berhubungan dengan anak yang stunting. Ibu dengan tubuh pendek kemungkinan akan melahirkan bayi yang pendek pula. Penelitian yang dilakukan di Mesir didapatkan bahwa ibu dengan tinggi badan $<150$ $\mathrm{cm}$ akan melahirkan anak yang memiliki risiko untuk tumbuh stunting (Amin, 2014). Orang tua yang memiliki tubuh pendek karena kekurangan hormon pertumbuhan akan memiliki gen kromosom dengan sifat pendek yang akan diwariskan sehingga anak berisiko untuk tumbuh pendek/stunting. Namun jika orang tua bertubuh pendek dikarenakan asupan gizi yang kurang atau suatu penyakit, kemungkinan anak akan tumbuh dengan tinggi badan yang normal selama anak mendapatkan asupan gizi yang baik dan tersebut tidak ada faktor risiko lain (Nasikhah \& Margawati, 2012).

Peneliti berasumsi bahwa meskipun seorang ibu memiliki kategori tinggi badan yang sangat pendek, masih memungkinkan untuk memiliki anak dengan tinggi normal ataupun sebaliknya ibu dengan tinggi normal masih memungkinkan untuk memiliki anak stunting. Hal ini menjelaskan bahwa genetik bukanlah satu-satunya faktor yang menentukan pertumbuhan dan perkembangan anak.

\section{Hubungan Pemberian ASI eksklusif dengan Kejadian Stunting}

Hasil analisis antara pemberian ASI eksklusif dengan kejadian stunting diketahui bahwa dari 60 balita yang mengalami kejadian stunting 


\section{JKM (Jurnal Kebidanan Malahayati),Vol 7,No.4.Oktober 2021, \\ ISSN (Print) 2476-8944 ISSN (Online) 2579-762X, Hal 688-696}

sebagian besar yaitu 32 responden $(26,67 \%)$ yang mendapatkan ASI eksklusif, sedangkan dari 60 balita yang tidak mengalami kejadian stunting (normal) sebagian besar yaitu 47 responden $(39,17 \%)$ yang mendapatkan ASI eksklusif. Hasil uji chi square $\left(x^{2}\right)$ diperoleh nilai $p$ value $0,007(<0,05)$ dengan menggunakan alpha $5 \%(0,05)$ dapat disimpulkan bahwa Ho ditolak yang artinya terdapat hubungan antara pemberian ASI eksklusif dengan kejadian stunting di Puskesmas Sepatan Kabupaten Tangerang dengan POR $=3,163$ (95\% Cl: 1,426$7,016)$ yang berarti balita yang tidak mendapatkan ASI eksklusif berpeluang 3 kali lebih besar mengalami stunting dibandingkan dengan balita yang mendapatkan ASI eksklusif.

Penelitian terkait pemberian ASI eksklusif sudah dilakukan oleh Satria dkk (2019) dimana didapatkan hubungan antara faktor pemberian ASI dengan kejadian stunting ( $p$ value $=0,001)$. Penelitian Sulistianingsih dan Sari (2018) membuktikan bahwa ASI eksklusif berpengaruh terhadap stunting dimana balita yang memperoleh ASI eksklusif berisiko 9,3 kali lebih kecil untuk terjadi stunting dibandingkan balita yang tidak memperoleh ASI eksklusif (Sastria, 2019; Sulistianingsih \& Sari, 2018).

Rendahnya pemberian ASI merupakan ancaman bagi tumbuh kembang anak yang akan berpengaruh pada pertumbuhan dan perkembangan kualitas sumber daya manusia secara umum. Pemberian ASI yang baik oleh ibu akan membantu menjaga ke-seimbangan gizi anak sehingga tercapai per-tumbuhan anak yang normal. ASI sangat dibutuhkan dalam masa pertumbuhan bayi agar kebutuhan gizinya tercukupi. Oleh karena itu ibu harus dan wajib memberikan ASI secara eksklusif kepada bayi sampai umur bayi 6 bulan dan tetap memberikan ASI sampai bayi berumur 2 tahun untuk memenuhi kebutuhan gizi bayi (Azriful et al., 2018).

Stunting dipengaruhi oleh riwayat pemberian ASI eksklusif dan penyakit infeksi, seperti diare dan Infeksi Saluran Pernapasan Akut (ISPA). Kebutuhan zat gizi bayi dapat dipenuhi dari ASI. Anak yang tidak mendapatkan ASI eksklusif berisiko lebih tinggi untuk kekurangan zat gizi yang diperlukan untuk proses pertumbuhan. Begitu juga anak yang mengalami infeksi rentan terjadi status gizi kurang. Anak yang mengalami infeksi jika dibiarkan maka berisiko terjadi stunting. ASI eksklusif dapat menurunkan risiko kejadian stunting, karena kandungan kalsium pada ASI mempunyai bioavailabilitas yang tinggi sehingga dapat diserap dengan optimal terutama dalam fungsi pembentukan tulang anak (Psoter et al., 2008).
Peneliti berasumsi bahwa ASI eksklusif dapat mempengaruhi kejadian stunting karena jika bayi yang belum cukup umur 6 bulan sudah diberi makanan selain ASI akan menyebabkan usus bayi tidak mampu mencerna makanan dan bayi akan mudah terkena penyakit karena kurangya asupan selain itu kandungan ASI sangat bermanfaat untuk membentuk sistem kekebalan tubuh bayi. Balita yang sering menderita penyakit infeksi akan menyebabkan pertumbuhannya terhambat dan tidak dapat mencapai pertumbuhan yang optimal.

\section{SIMPULAN}

Terdapat hubungan tinggi badan ibu dan pemberian ASI eksklusif dengan kejadian stunting. Tidak terdapat hubungan tinggi badan ayah dengan kejadian stunting.Perlunya edukasi secara rutin untuk meningkatkan pengetahuan masyarakat tentang pertumbuhan dan perkembangan balita sehingga mengetahui faktor yang mempengaruhi permasalahan pertumbuhan balita khususnya stunting sehingga mampu melakukan tindakan pencegahan kejadian stunting.

\section{SARAN}

Diharapkan petugas kesehatan di Puskesmas agar memberikan informasi kepada masyarakat dan orang tua agar memberikan ASI Eksklusif dan memperhatikan pola asuh yang baik, baik dalam pemantauan keadaan gizi dan penyakit yang dialami oleh anaknya. Meningkatkan peran kader dalam scrining stunting pada balita untuk meningkatkan cakupan penemuan kasus stunting.

\section{DAFTAR PUSTAKA}

Amin, N. A., \& Julia, M. (2016). Faktor sosiodemografi dan tinggi badan orang tua serta hubungannya dengan kejadian stunting pada balita usia 6-23 bulan. Jurnal Gizi Dan Dietetik Indonesia (Indonesian Journal of Nutrition and Dietetics), 2(3), 170. https://doi.org/10.21927/ijnd.2014.2(3).170177

Azriful, A., Bujawati, E., Habibi, H., Aeni, S., \& Yusdarif, Y. (2018). Determinan Kejadian Stunting Pada Balita Usia 24-59 Bulan di Kelurahan Rangas Kecamatan Banggae Kabupaten Majene. Al-Sihah: The Public Health Science Journal, 10(2), 192-203. https://doi.org/10.24252/as.v10i2.6874

Barir, B., Murti, B., \& Pamungkasari, E. P. (2019). The Associations between Exclusive Breastfeeding, Complementary Feeding, and the Risk of Stunting in Children Under Five Years of Age: A Path Analysis Evidence from 
Jombang East Java. Journal of Maternal and

Child Health, 4(6), 486-498. https://doi.org/10.26911/thejmch.2019.04.06. 09

Cleaton-Jones, P., Richardson, B. D., Granath, L., Fatti, L. P., Sinwell, R., Walker, A. R., \& Mogotsi, M. (2000). Nutritional status and dental caries in a large sample of 4- and 5year-old South African children. South African Medical Journal.

Kemenkes. (2018). Buletin Jendela Data dan Informasi Kesehatan: Stunting di Indonesia.

Kementrian Kesehatan RI. (2018). Riset Kesehatan Dasar (Riskesdas).

Kramer, M. S., \& Kakuma, R. (2002). The optimal duration of exclusive breastfeeding. Tropical Doctor, 32(1), 62-63. https://doi.org/10.1002/14651858.cd003517. pub2

Mugianti, S., Mulyadi, A., Anam, A. K., \& Najah, Z. L. (2018). Faktor penyebab anak stunting usia 25-60 Bulan di Kecamatan Sukorejo Kota Blitar. Jurnal Ners Dan Kebidanan (Journal of Ners and Midwifery), 5(3), 268278.

https://doi.org/10.26699/jnk.v5i3.art.p268278

Nasikhah, R., \& Margawati, A. (2012). Prevalensi stunting di Jawa Tengah kejadian tertinggi di Kecamatan Semarang Timur. Journal of Nutrition College, 1(1), 176-184. ejournals1.undip.ac.id

Ohyver, M., Moniaga, J. V, Yunidwi, K. R., \& Setiawan, M. I. (2017). Logistic Regression and Growth Charts to Determine Children Nutritional and Stunting Status: A Review. Procedia Computer Science, 116, 232-241. https://doi.org/https://doi.org/10.1016/j.procs. 2017.10.045

Psoter, W., Gebrian, B., Prophete, S., Reid, B., \& Katz, R. (2008). Effect of early childhood malnutrition on tooth eruption in Haitian adolescents. Community Dentistry and Oral Epidemiology. https://doi.org/10.1111/j.16000528.2007.00386.x

Ratu, N. C., Punuh, M. I., Malonda, N. S. H., Kesehatan, F., Universitas, M., \& Ratulangi, S. (2010). USIA 24-59 BULAN DI KECAMATAN RATAHAN KABUPATEN MINAHASA TENGGARA PENDAHULUAN Gizi merupakan salah satu faktor yang tercapainya keberhasilan yang optimal bagi tumbuh kembang Periode emas stunting di Indonesia sendiri menurut hasil riset kesehatan dasar me. Jurnal Kesmas, 7(8), 1-8.

Sastria, A. (2019). Faktor Kejadian Stunting Pada Anak Dan Balita. Jurnal IImiah Keperawatan Stikes Hang Tuah Surabaya Vol. 14 No. 2 October 2019 Print ISSN 2085-3742 Online ISSN 2598-1021 Www.Journal.Stikeshangtuah-Sby.Ac.Id, 14(2), 100-108.

Sulistianingsih, A., \& Sari, R. (2018). ASI eksklusif dan berat lahir berpengaruh terhadap stunting pada balita 2-5 tahun di Kabupaten Pesawaran. Jurnal Gizi Klinik Indonesia, 15(2), 45. https://doi.org/10.22146/ijcn.39086

Surmita, Noparini, I., Dewi, M., Witri Priawantiputri, \& Fitria, M. (2019). Hubungan Tinggi Badan Orang Tua dan Kejadian Stunting Pada Balita. Jurnal Riset Kesehatan, 11(1), 387391.

Torlesse, H., Cronin, A. A., Sebayang, S. K., \& Nandy, R. (2016). Determinants of stunting in Indonesian children: evidence from a cross-sectional survey indicate a prominent role for the water, sanitation and hygiene sector in stunting reduction. BMC Public Health, $\quad 16(1), \quad 669$. https://doi.org/10.1186/s12889-016-3339-8 